\title{
KroONIKA
}

\section{LÄÄNEMERE REGIOONI REFORMATSIOONIAJALOO KONVERENTS VILNIUSES}

Lähenev reformatsiooni alguse 500. aastapäev 2017. aastal tähendab reformatsiooniajaloo tõusu nii laiema teaduspubliku kui ka lihtsalt kultuurihuvilise seltskonna vaatevälja. Olulise tõuke on see andnud ka reformatsiooniuuringutega otseselt tegelevale teadlaskonnale.

Vilniuse ülikoolis toimus 9.-13. septembril 2015 esinduslik teaduskonverents Reformatio baltica. Reformatsiooni kultuurimõjud Lä̈̈nemere regiooni metropolides. Ühised uurimishuvid tõid kokku üle saja teadlase Saksamaalt, Taanist, Norrast, Rootsist, Soomest, Eestist, Lätist, Leedust, Poolast, Itaaliast, Ameerika Ühendriikidest, Kanadast ja Venemaalt. Osalejate seas leiame erinevate reformatsiooniuuringutega seotud teadusalade esindajaid.

Konverentsi kontseptsiooni autoriteks ja põhikorraldajateks olid prof Johann Anselm Steiger Hamburgi ülikoolist, prof Axel E. Walter Klaipeda ülikoolist ja prof Heinrich Assel Greifswaldi ülikoolist. Teoreetilise lähtealusena pakuti välja kaks viimase aja uuemat suunda humanitaarteadustes: võrdlev suurlinnauurimine (Metropolforschung) ja ajaloolise kultuuridevahelise kommunikatsiooni (Kulturtransfer) uurimine, mis andsid üheskoos täpsema aktsendi oma sisult ju erakordselt laiale ja mitmetahulisele teemaderingile reformatsiooni mõjudest Läänemere ruumi poliitilises, sotsiaal-, majandus-, kiriku-, õigus- ja kunstiajaloos 16.-18. sajandil. Koondades eriteadlasi paljudest uurimiskeskustest ja uurimisvõrgustikest on kõnealune konverents Läänemere regioonis eelmainitud uurimistemaatika osas seni ainulaadne nii oma uurimisprobleemide geograafiliselt haardelt kui ka interdistsiplinaarselt käsitlusulatuselt.

Lisaks arvukatele plenaarettekannetele toimus töö viies sektsioonis: 1) Püha Rooma Keisririik; 2) Poola-Leedu riik ja Preisi hertsogiriik; 3) Baltimaad; 4) Skandinaavia; 5) Reformatsiooniteooria ja reformatsioonikultuur. Eesti teadlased panustasid ootuspäraselt Baltikumi sektsiooni tegevusse. Jüri Kivimäe Toronto ülikoolist keskendus Tallinna linna temaatikale 16. sajandil (Bücher und Prediger: Der Revaler Mikrokosmos im 
Reformationszeitalter). Tiiu Reimo Tallinna ülikoolist käsitles Eestimaa kirikuvalitsuse kirjastustegevust uuemal ajal (Die Verlagstätigkeit des estländischen Provinzialkonsistoriums im 18. und 19. Jahrhundert). Teised ettekandjad esindasid kõik Tartu ülikooli. Riho Altnurme andis ülevaate kirikukorralduse kujunemisest Rootsi aja algupoolel (Die Gründung der evangelischen Kirche in der schwedischen Zeit). Andres Andresen uuris kirikuõiguslikke arenguid reformatsioonijärgsel perioodil (Die nachreformatorische Kirchenrechtsordnung in Estland und Livland: Partikularisierung, Zentralisierung, Modernisierung). Kristi Viidingu teemaks olid reformatsioonimõjud humanistlikus kirjanduses (Reformation als Anstoß zur Entwicklung der humanistischen Literatur in Est- und Livland im 16. und 17. Jahrhundert). Kaarina Rein võttis vaatluse alla arstiteaduse ja teoloogia rootsiaegses Tartus (Medizin und Theologie im Tartu des 17. Jahrhunderts). Konverentsi ettekanded avaldatakse mitmeköitelises kogumikus 2017. aastal.

Võib tekkida küsimus, miks korraldati selline konverents just Vilniuses, kunagise katoliikliku Poola riigi ühes suuremas keskuses? Korraldajad viitasid asjaolule, et Vilniuse ülikool on reformatsiooniajastu sünnitis. Igal juhul andis Vilniuse ülikooli vana hoonetekompleks - kunagine jesuiitide akadeemia - kogu ettevõtmisele erilise õhustiku, mida pole iialgi võimalik saavutada modernsetes konverentsisaalides.

Andres Andresen

\section{LOOMUÕIGUS EUROOPA ÜLIKOOLIDES 1625-1850}

1625. aastal ilmus Pariisis Madalmaade päritolu õpetlase Hugo Grotiuse teos "Sõja ja rahu õigusest" (De iure belli ac pacis), mida on sageli peetud esimeseks süstemaatiliseks rahvusvahelise õiguse käsitluseks. Kas Grotius oli rahvusvahelise õiguse "isa" või mitte, selle üle on pikalt vaieldud, ent kindlalt võib väita, et Grotiuse suurteos avaldas varauusaja ideedeajaloole mõju, mis ulatus kaugemale rahvusvahelise õiguse süstematiseerimisest. Grotius seadis eesmärgiks sõnastada universaalsed õigusprintsiipid, mis oleksid aluseks ja mõõdupuuks nii riigisisesele kui riikidevahelisele õigusele. Selleks kasutas ta "loomuõiguse" (ius naturae) mõistet, mida erinevates 